\section{The New Design Criteria For Steel Construction Concerning Occupational Health And Safety}

\author{
Surya Hermawan ${ }^{1}$, Gunawan Budi Wijaya ${ }^{2}$ \\ 1Dosen Program Studi S1, S3 Teknik Sipil dan Perencanaan \\ dan Program Profesi Insinyur Universitas Kristen Petra
}

${ }^{2}$ Dosen Program Studi S1 Teknik Sipil dan Perencanaan dan Program Profesi Insinyur Universitas Kristen Petra

\section{shermawan@petra.ac.id}

In Indonesia, the number of construction project increased, while the Occupational Health and Safety (OHS) is one of the main purposes of the construction project. However, the OHS is often neglected which is indicated by the high number of the work accident occurrences. To reduce the work risk, a safe design since the pre-construction stage which is often called prevention through design should be considered. In this research, the method was carried out by a literature study to collect theory and data from some sources, including journal, thesis and website which initiated by the National Institute of Occupational Safety and Health (NIOSH). Then, the research continued to field observation for collecting the references to help formulate the new design criteria. The outcome of this research demonstrates that the prevention step for the work accident should be done earlier in the project, which is in the design phase. By doing prevention, such as using the new design criteria with the OHS consideration or the prevention through design, could reduce the work accident risk that could occur in steel construction project. The new design criteria discussing 5 elements in steel structure including column, beam, rafter, endplate connection and angle plate connection by applying the elements of the OHS in advance.

Keywords: new design criteria, steel construction, occupational health and safety

Diajukan: 13 September 2019

Direvisi: 14 September 2019

Diterima: 2 Oktober 2019

Dipublikasikan online: 3 Oktober 2019

\section{Introduction}

Every year the number of construction project increased in Indonesia since Indonesia is a developing country, then the enhancements in quality and quantity of infrastructure are needed. On the other hand, the increasing construction project means the chance of work accident would be increased too. In 2015 and 2016 , the number of work accidents in Indonesia at construction sector reached 110.285 cases and 101.367 cases, respectively, then in 2017 the number of work accident reduced around 20.975 cases to 80.393 cases (BPJS Ketenagakerjaan, 2017) . The decreasing of work accident every year means the developing of OHS implementation in Indonesia are at a good pace. However, the number is still showing a pretty high number.

To reduce the number of a work accident in Indonesia, an OHS instrument is needed, especially for local contractor. This instrument hopefully could reduce the work accident risk in construction sector in Indonesia. The instrument created in the form of a list of design criteria which considering OHS in the design phase (Szymberski, 1997; Behm, 2005; Toole and Gambatase, 2014). The criteria used to help the designer in designing a steel structure with a lower work accident risk.

\section{Literature Study}

\section{Prevention Through Design}

Prevention through Design (PtD), was more known as Design for Safety (DfS) in some European country. PtD was a consideration of the safety of the construction process in the design phase. The main purpose of PtD was to reduce the risk which was attached to the worker (Toole et al, 2006). PtD itself was a program or method to prevent the work accident initiated by the National Institute of Occupational Safety and Health (NIOSH).

Regarding hazard control, this research uses engineering controls which is one of risk controlling in hierarchy of controls (NIOSH, 2016). Engineering controls are a hazard control which modifies or change the design existed, so the risk of work accident occurrence would be lower. The using of engineering controls in this research is to modify the design with a higher risk of work accident into a lower risk work accident design. This modification is based on the assessment using the criteria created. Through the design phase, several PtD applications can be implemented, such as identifying anchorage points, allocating guard rail holes in vertical steel elements, avoiding hanging connections and eliminating sharp

Cara mensitasi artikel ini:

Hermawan, S, and Wijaya, G.B (2019) The New Design Criteria For Steel Construction Concerning Occupational Health And Safety. Buletin Profesi Insinyur 2(2) 051-055 
corners (Toole and Gambatase, 2014; NIOSH, 2013; Toole, 2013).

There are 5 barriers in implementing PtD including: the first is the designer's fear of liability toward worker safety and the exposure to third-party lawsuits. The second is the increase in design fees due to the extra time that designers spend to incorporate safety measures in the design. The third is the lack of the designers' safety expertise that is articulated in identifying and installing safety measures and alternatives during the design phase (Toole, 2005; Toole and Carpenter, 2012; Malcolm, 2008; Rajendran and Gambatase, 2012). The fourth is the lack of regulatory requirements in the U.S, which differ from other countries such as UK, Australia, and Singapore. Finally, yet most importantly, the fifth is the lack of education and training among the Architecture, Engineering and Construction (AEC) Industry professionals and AEC academic curriculum regarding the PtD concept and implementation (Gambatase, 2013; NIOSH, 2014).

\section{Constructability}

Constructability is a project management technique to review the construction progress from the beginning to the end in the pre-construction phase. The purpose is to identify the obstacles that could happen before the project held to reduce and prevent error in a project, delay and extra cost (Wiryawan and Thendeyas, 2012).

\section{Lifting Equipment, Bolt Fasteners and Weld-In Stee Construction}

According to $\mathrm{NIOSH}$, the maximum load lifted by a worker without any lifting equipment is $23 \mathrm{~kg}$. Based on this statement, the material removal with a pretty big load and dimension required lifting equipment such as chain block, mobile crane and tower crane. There are some things to be considered in the usage of lifting equipment such as the load lifted by the equipment should not passing the load limit capacity or often called Safe Working Load (SWL).

In the implementation of steel construction, a connection is one of the things should be considered. The connection in steel construction according to the work method divided into 2 types, which is weld and bolt. In the erection process, there should be enough space and access for the worker hand and the equipment. There should be a consideration for choosing the right equipment would be used based on the dimension since the design process so there would be enough space for the worker. Other than that, there are some things to consider such as the awkward or dangerous working position for the worker.

\section{Research Method}

In this research, the method was carried out by a literature study to collect theory and data from some source such as journal, thesis and website. Then, the research continued to field observation for collecting the references to help formulate the design criteria. The design criteria used in the design assessment made based on the literature study and field observation. These criteria include some condition that should be considered to rate the implementation of OHS. After the criteria finished, the next things are analyzing the construction drawing to see and rate the safety level of the steel structure design. In analyzing the drawing, the design criteria that have been made used to rate the safety level of the design.

\section{Results}

Regarding the literature study and field observation, there are some criteria related to steel construction design which consider the OHS. This design criterion made to help the steel structure designer in implementing OHS since the design phase. The criteria divided into 4 part of structural element, including column, beam, rafter and connection (endplate and angle plate). The main purpose criteria are to increase worker safety since the construction phase. The criteria divided into three categories, unsuitable, allowed and suitable. The category is to help to get the final score of OHS implementation in the related project. In the assessment phase, every category has a score each 0,1 and 2, for: 0 points are given to the criteria that categorized as unsuitable, 1 point for the allowed criteria and 2 points for the suitable criteria. The criteria of column, beam and rafter could be seen in Table 1 . And the criteria for the endplate connection and angle connection could be seen in Table 2 .

As can be seen in Table 1, no. 1 for column section, there are seven criteria including lifting hole, guardrail availability, harness hole, pedestal column height, number of anchorages, splices location, member weight. Regarding this section, some sources of the criteria are gained from the National Institute of Occupational Safety and Health (NIOSH) and others are made during this research. The same interpretation is implemented for beam, rafter, connection along with angel plate connection.

Lifting hole in a column is to provide a spot to hook or tie lifting rope. This is meant to reduce the falling risk of the column because of the lifting rope not tied properly or slipped. Guardrail availability is to provide a guardrail on the edge of the building in a relatively high elevation, to reduce the falling risk of the worker. Guardrail at least provide in 1 spot in $1000 \mathrm{~mm}$ elevation, but more recommended to provide in 2 spots, in $500 \mathrm{~mm}$ and $1000 \mathrm{~mm}$ elevation. A harness hole is to provide a spot to hook up the harness or rope. For the column, this hole at least should be provided in 1 spot at the flange section of the column and provide the hole at least above the worker head $( \pm 200 \mathrm{~cm})$. To prevent the worker tripped, pedestal column should be designed at least $300 \mathrm{~mm}$ high. But if the pedestal column has $150-300 \mathrm{~mm}$ height, there should be a tripping hazard or barricade around the pedestal column.

Table 1. Design Criteria for Column, Beam and Rafter 


\begin{tabular}{|c|c|c|c|c|c|}
\hline \multirow{2}{*}{ No. } & \multirow{2}{*}{ Item } & \multicolumn{3}{|c|}{ Criteria } & \multirow{2}{*}{ Source } \\
\hline & & Unsuitable & Allowed & Suitable & \\
\hline \multirow[t]{8}{*}{1.} & Column & & & & \\
\hline & Lifting hole & None & $\begin{array}{l}1 \text { point with } 1-3 \text { hole(s) } \\
\text { (flange) }\end{array}$ & $\begin{array}{c}1 \text { point } 1 \text { hole (web) } \\
1 \text { point with } 4 \text { holes } \\
\text { (flange) }\end{array}$ & \\
\hline & Guradrail availability & None & 1 point & 2 points & NIOSH \\
\hline & Harness hole & None & 1 point & 1 point overhead & NIOSH \\
\hline & Pedestal column height & $<150 \mathrm{~mm}$ & $150 \mathrm{~mm} \leq \mathrm{x} \leq 300 \mathrm{~mm}$ & $>300 \mathrm{~mm}$ & \\
\hline & Number of anchorage & $<2$ anchorages & $2-3$ anchorages & $\geq 4$ anchorages & NIOSH \\
\hline & Splices Location & $\begin{array}{c}<600 \mathrm{~mm} \text { or }>1600 \\
\mathrm{~mm}\end{array}$ & $\begin{array}{c}600-1000 \mathrm{~mm} \text { or } 1400- \\
1600 \mathrm{~mm}\end{array}$ & $1000-1400 \mathrm{~mm}$ & NIOSH \\
\hline & Member Weight & $\begin{array}{l}\geq S W L \text { (machine) or } \\
>30 \mathrm{~kg} / \text { manpower }\end{array}$ & $\begin{array}{c}90-99 \% \mathrm{SWL} \text { (machine) or } \\
20-30 \mathrm{~kg} / \text { manpower }\end{array}$ & $\begin{array}{l}<90 \% \text { SWL (machine) } \\
\text { or } \leq 20 \mathrm{~kg} / \text { manpower }\end{array}$ & \\
\hline \multirow[t]{6}{*}{2.} & Beam & & & & \\
\hline & Lifting hole & None & 2 points with 1 hole each & $\begin{array}{l}2 \text { points with } 1 \text { hole } \\
\text { each (web) } / 2 \text { points } \\
\text { with } 2 \text { or } 4 \text { holes each } \\
\text { (flange) }\end{array}$ & \\
\hline & Flange width & $<150 \mathrm{~mm}$ & $150-200 \mathrm{~mm}$ & $>200 \mathrm{~mm}$ & NIOSH \\
\hline & Harness hole & None & 1 hole for every $>1000 \mathrm{~mm}$ & $\begin{array}{l}1 \text { hole for every } 1000 \\
\mathrm{~mm}\end{array}$ & NIOSH \\
\hline & Splices Location & $0.35-0.65 \mathrm{~L}$ & $\begin{array}{c}0.00-0.20 \mathrm{~L}, 0.30-0.35 \mathrm{~L} \\
0.65-0.70 \mathrm{~L}, \text { or } 0.80-1.00 \mathrm{~L}\end{array}$ & $\begin{array}{c}0.20-0.30 \mathrm{~L} \text { or } \\
0.80 \mathrm{~L}\end{array}$ & \\
\hline & Member Weight & $\begin{array}{l}\geq \text { SWL (machine) or } \\
>30 \mathrm{~kg} / \text { manpower }\end{array}$ & $\begin{array}{c}90-99 \% \text { SWL (machine) or } \\
20-30 \mathrm{~kg} / \text { manpower }\end{array}$ & $\begin{array}{l}<90 \% \text { SWL (machine) } \\
\text { or } \leq 20 \mathrm{~kg} / \text { manpower }\end{array}$ & \\
\hline \multirow[t]{5}{*}{3.} & Rafter & & & & \\
\hline & Lifting hole & None & $\begin{array}{l}1 \text { point with } 4 \text { holes } \\
\text { (flange) }\end{array}$ & $\begin{array}{l}3 \text { points with } 1 \text { hole } \\
\text { each (web) } / 3 \text { points } \\
\text { with } 2 \text { holes each } \\
\text { (flange) }\end{array}$ & \\
\hline & Hamess hole & None & $\begin{array}{l}1 \text { hole for every } 1000 \mathrm{~mm} \text { - } \\
\qquad 2000 \mathrm{~mm}\end{array}$ & $\begin{array}{l}1 \text { hole for every } 1000 \\
\mathrm{~mm}\end{array}$ & \\
\hline & Splices Location & $0.35-0.65 \mathrm{~L}$ & $\begin{array}{c}0.00-0.20 \mathrm{~L}, 0.30-0.35 \mathrm{~L} \\
0.65-0.70 \mathrm{~L}, \text { or } 0.80-1.00 \mathrm{~L}\end{array}$ & $\begin{array}{c}0.20-0.30 \mathrm{~L} \text { or } 0.70- \\
0.80 \mathrm{~L}\end{array}$ & \\
\hline & Member Weight & $\begin{array}{l}\geq S W L \text { (machine) or } \\
>30 \mathrm{~kg} \text { /manpower }\end{array}$ & $\begin{array}{c}90-99 \% \text { SWL (machine) or } \\
20-30 \mathrm{~kg} / \text { manpower }\end{array}$ & $\begin{array}{l}<90 \% \text { SWL (machine) } \\
\text { or } \leq 20 \mathrm{~kg} / \text { manpower }\end{array}$ & \\
\hline
\end{tabular}

The number of anchors for the column recommended is 4 point in the four different quadrants, so the column could withstand 2 ways force equally. But if the usage of least than 4 anchors desired, there should be at least 2-3 anchor with the position and number calculated carefully to withstand 2 ways force. The position of column splices recommended is in the $1000-1400 \mathrm{~mm}$ elevation or at worker chest height to prevent an awkward or difficult work position. If not possible, the minimum height allowed is around $600-$ $1000 \mathrm{~mm}$ or $1400-1600 \mathrm{~mm}$. The reason for this elevation is because the worker could have a difficult work position to do the work.

The recommended member weight to be lifted is < $60 \%$ from the Safe Working Load (SWL) with lifting machine and for the manpower or manual, the recommended member weight to be lifted or pulled by pulley is $\leq 20 \mathrm{~kg} /$ person. But if not possible, the allowed load to be lifted by the lifting machine is $60-80 \%$ SWL and for the manpower or manual is $20-30 \mathrm{~kg} /$ person. Lifting hole for beam should be provided at least located in 2 spots and each has 1 hole in the flange section. But its more recommended the lifting hole provided at least located in 2 spots and each has 1 hole in the web section or 2 spots each has 2 or 4 holes for the flange section. The minimum width of beam flange is $150-200 \mathrm{~mm}$ to provide the beam as a footing for the worker if necessary. But more recommended if the flange width wider than $200 \mathrm{~mm}$. Harness hole for beam at least provide 1 hole in the bottom flange section with the distance between the hole around $1000 \mathrm{~mm}$ to 2000 $\mathrm{mm}$ each hole. But more recommended if there is 1 hole in the bottom flange section each $1000 \mathrm{~mm}$ distance. The position of beam splices at least provided in the $0.00-0.20$ span, $0.30-0.35$ span, $0.65-0.70$ span or $0.80-1.00$ span. But more recommended to provide in the $0.20-0.30$ span or 0.70 to 0.80 span.

Table 2. Design Criteria for Connection 


\begin{tabular}{|c|c|c|c|c|c|}
\hline \multirow{2}{*}{ No. } & \multirow{2}{*}{ Criteria } & \multicolumn{3}{|c|}{ Criteria } & \multirow{2}{*}{ Source } \\
\hline & & Unsuitable & Allowed & Suitable & \\
\hline \multirow[t]{12}{*}{4.} & Connection & & & & \\
\hline & End Plate Connection & & & & \\
\hline & Dummy hole / seats & None & 1 dummy hole & $\begin{array}{c}1 \text { seat } / 2 \text { dummy } \\
\text { holes }\end{array}$ & NIOSH \\
\hline & $\begin{array}{l}\text { Number of bolts each } \\
\text { connection (Moment) }\end{array}$ & $1-2$ bolt(s) & $\begin{array}{c}3 \text { bolts in } 2 \text { rows or }>4 \\
\text { bolts in } 2 \text { rows }\end{array}$ & 4 bolts in 2 rows & \\
\hline & $\begin{array}{l}\text { Number of bolts each } \\
\text { connection (shear) }\end{array}$ & 1 bolt & $>2$ bolts & 2 bolts & \\
\hline & Double connection & Without Support & $\begin{array}{l}1 \text { support (dummy hole or } \\
\text { angle plate) }\end{array}$ & $\begin{array}{l}2 \text { supports (dummy } \\
\text { hole or angle plate) }\end{array}$ & NIOSH \\
\hline & Angle plate connection & & & & \\
\hline & Dummy hole / seats & None & 1 dummy hole & $\begin{array}{c}1 \text { seat } / 2 \text { dummy } \\
\text { holes }\end{array}$ & NIOSH \\
\hline & $\begin{array}{l}\text { Number of bolts each } \\
\text { connection (Moment) }\end{array}$ & $1-2$ bolt(s) & $\begin{array}{c}3 \text { bolts in } 2 \text { rows or }>4 \\
\text { bolts in } 2 \text { rows }\end{array}$ & 4 bolts in 2 rows & \\
\hline & $\begin{array}{l}\text { Number of bolts each } \\
\text { connection (shear) }\end{array}$ & 1 bolt & $>2$ bolts & 2 bolts & \\
\hline & Double connection & Without Support & $\begin{array}{c}1 \text { support (dummy hole or } \\
\text { angle plate) }\end{array}$ & $\begin{array}{l}2 \text { supports (dummy } \\
\text { hole or angle plate) }\end{array}$ & NIOSH \\
\hline & Hanging connection & Exist & $\mathrm{N} / \mathrm{A}$ & Not exist & NIOSH \\
\hline
\end{tabular}

Lifting hole for rafter should be provided at least located on 1 spot with 4 holes each at flange section. But more recommended the lifting hole provided at least at 3 spots with 1 hole each for the web section or 3 spots with 2 or 4 holes each for flange section. The endplate connection or angle connection at least should have 1 dummy hole. But more recommended to provided 1 seat or 2 dummy holes. The purpose of providing dummy hole or seats is to provide a temporary seat for the member while being connected. The endplate connection or angle connection at least have 3 bolts or more than 4 bolts that located in 2 different rows for the moment connection. But more recommended to provide 4 bolts in 2 different rows. The decision of the number bolt is to optimize the number of bolts used so the work duration for the worker in the high elevation could be reduced. The endplate connection or angle connection should have at least more than 2 bolts for the shear connection. But more recommended to provide 2 bolts to optimize the number of bolts used so the work duration for the worker in the high elevation could be reduced. For the double connection, there should be at least a support (dummy hole) for one side of the connection. But more recommended to provide support for both sides of the connection in the form of dummy hole or seats. This support is to reduce the falling risk of the member while the member being connected in the state of the bolts has not fastened. The usage of the hanging connection should be avoided because the connection does not have a support that could hold the member if the connection failed.

\section{Conclusion}

The conclusions of the research are:

1. The prevention step for the work accident should be done earlier in the project, which is in the design phase. By doing prevention, such as using the design criteria with OHS consideration or the prevention through design, could reduce the work accident risk that could occur in steel construction project.

2. The design criteria discussing 5 elements in steel structure including column, beam, rafter, endplate connection and angle plate connection. Each element has some criteria that should be considered regarding the $\mathrm{OHS}$.

\section{Reference}

BPJS Ketenagakerjaan (2017, February 1). Kecelakaan Kerja Konstruksi 2017 Diprediksi Tetap Tinggi. Safety Magazine. Retrieved March 1, 2018, from http://isafetymagz.com/2017/02/01/kecelak aan-kerja-konstruksi-2017-diprediksi-tetap-tinggi/

Szymberski, R. (1997). Construction Project Safety Planning. TAPPI Journal. 80(11), p.69-74.

Behm, M. (2005). Linking Construction Fatalities to the Design for Construction Safety Concept. Safety of Science. 43(8), p.589-611.

Toole, T. M., \& Gambatese, J. A. (2014). Prevention Through Design: A Path to Social Sustainability. Owners Perspective - The Magazine of The Construction Owners Association of America.

Toole, T.M., Hervol, N. \& Hallowell, M. (2006). Design for construction safety: taking construction safety into 
account during the design phase of a project is become more and more common.

NIOSH (2016, July 29). Prevention Through Design. CDC. Retrieved May 20, 2018, from https://www.cdc.gov/niosh/topics/ptd/

NIOSH (2013, July). Structural Steel Design Education Module. Retrieved September 1, 2018, from https://www.cdc.gov/niosh/topics/ptd/pubs.html

Toole, T.M. (2013). Prevention Through Design: A Leadership Opportunity for You. Retrieved September 3, 2018, from http://www.facstaff.bucknell.edu/ttoole/Toole\%20 COAA\%20presentation\%20on\%20PtD.pdf

Toole, T. M. (2005). Increasing engineers' role in construction safety: Opportunities and barriers. Journal of Professional Issues in Engineering Education and Practice, 131(3), 199-207.

Toole, T., \& Carpenter, G. (2012). Prevention through Design as a Path toward Social Sustainability. Journal of Architectural Engineering, 19(3), 168173. DOI:10.1061/(ASCE)AE.1943-5568.0000107

Malcolm, C. (2008). Building the Case for Prevention through Design Presentation-Kaiser Permanente, Journal of Safety Research, 39, 151-152.
Rajendran, S., \& Gambatese, J. (2012). Risk and Financial Impacts of Prevention through Design Solutions. Practice Periodical on Structural Design and Construction, 18(1), 67-72. DOI:10.1061/(ASCE)SC.1943-5576.0000129

Gambatese, J. (2013). Final Report - Activity 2: Assess the Effects of PtD Regulations on Construction Companies in the UK. Retrieved September 6, 2018, from

http://www.designforconstructionsafety.org/Docu ments/NIOSH\%2OPtD\%20in\%20the\%20U\%20\%20Final\%20Report\%20-\%20May\%202013.pdf

$\mathrm{NIOSH}$. (2014). The State of the National Initiative on Prevention through Design - PROGRESS REPORT 2014. Retrieved September 6, 2018, from http://www.cdc.gov/niosh/docs/2014123/pdfs/2014-123_v2.pdf

Wiryawan, T.A., Thendeyas, W.T. (2012). Prinsip-Prinsip Constructability pada Proyek Konstruksi di Surabaya. (TA No. 21011852/SIP/2012). Universitas Kristen Petra, Surabaya. 